\title{
Teaching NeuroImages: Optic nerve sheath meningioma presenting as gaze-evoked amaurosis
}

Stephen A. Johnson, MD, John J. Chen, MD, PhD, and W. Oliver Tobin, MBBCh, BAO, PhD

Neurology ${ }^{\circledR}$ 2018;90:e2095-e2096. doi:10.1212/WNL.0000000000005642

Figure Imaging shows optic nerve edema, calcification, and postgadolinium enhancement consistent with optic nerve sheath meningioma
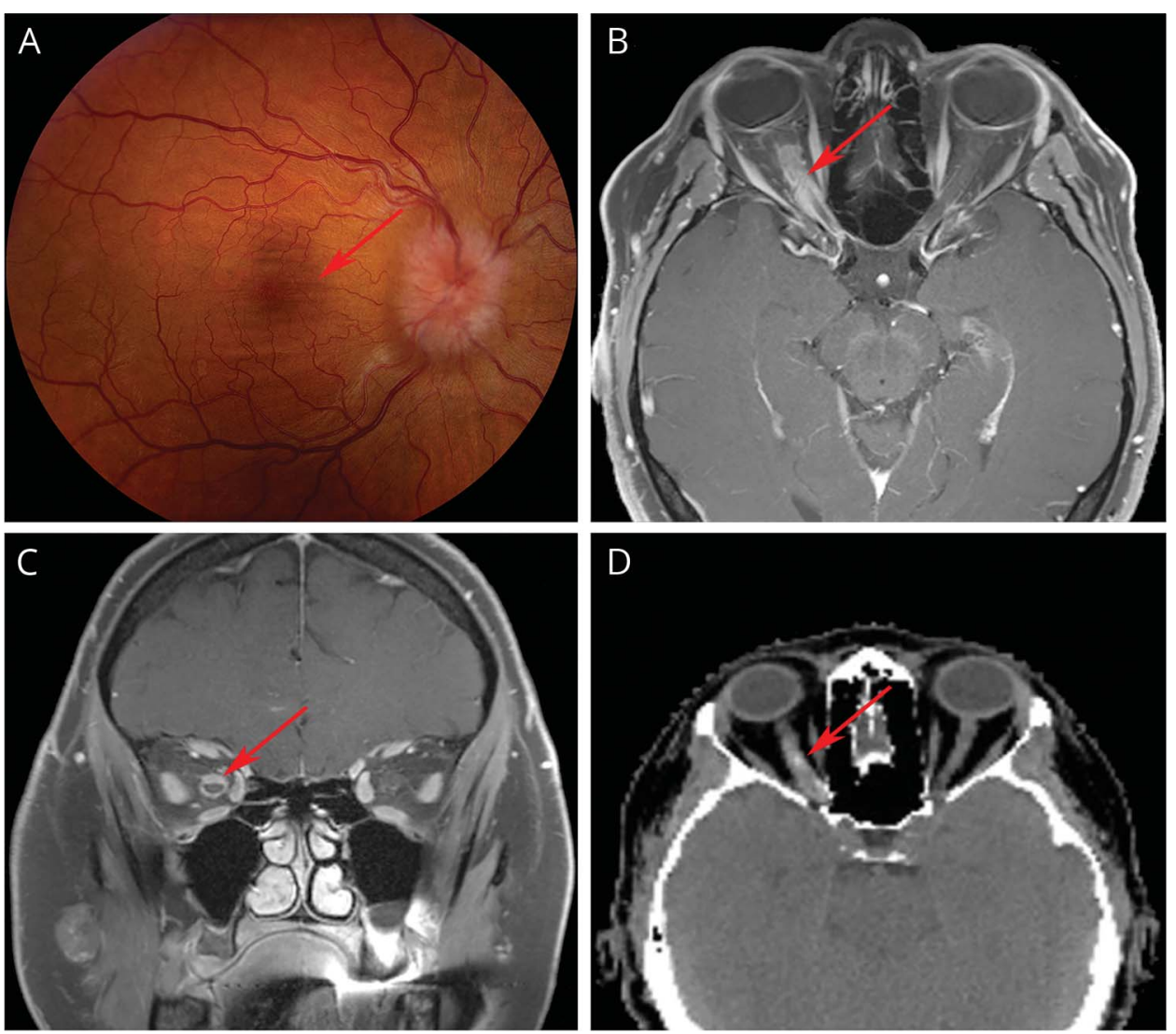

Fundus photograph of the right eye demonstrates moderate to severe optic disc edema and choroidal folds (arrow) (A). Orbital MRI reveals circumferential postgadolinium enhancement of the right optic nerve sheath (arrows) (B, C). CT of orbits demonstrates calcification of the right optic nerve (arrow) (D).

A 47-year-old woman reported a slowly progressive 15-month history of intermittent visual loss on rightward gaze as well as diminished visual acuity of her right eye. Examination revealed right ocular red desaturation, afferent pupillary defect, impaired visual acuity, and optic disc swelling (figure, A). Head imaging revealed an optic nerve sheath meningioma (figure, B and C). A brain MRI performed 4 months prior to the current evaluation displayed a similar pattern of optic nerve enhancement. Gaze-evoked amaurosis is transient monocular visual loss on eccentric gaze. It is suggestive of intraconal

\section{Correspondence}

Dr. Tobin

Tobin.Oliver@mayo.edu

\section{MORE ONLINE}

\section{$\rightarrow$ Teaching slides}

links.lww.com/WNL/ A509

From the Departments of Neurology (S.A.J., J.J.C., W.O.T.) and Ophthalmology (J.J.C.), Mayo Clinic Rochester, MN.

Go to Neurology.org/N for full disclosures. Funding information and disclosures deemed relevant by the authors, if any, are provided at the end of the article. 
pathology and is putatively caused by position-dependent occlusion of the retinal or optic nerve circulation. ${ }^{1}$ The most common causes of gaze-evoked amaurosis are optic nerve sheath meningioma and cavernous hemangioma. ${ }^{1}$ Treatment options for optic nerve sheath meningioma include observation, radiotherapy, radiosurgery, and resection. $^{2}$

\section{Author contributions}

Stephen A. Johnson: preparation of manuscript. John J. Chen: review of manuscript, funduscopic imaging. W. Oliver Tobin: review and supervision of manuscript.

\section{Study funding}

This work was supported in part by an unrestricted grant to the Department of Ophthalmology by Research to Prevent Blindness, Inc., New York, NY.

\section{Disclosure}

The authors report no disclosures relevant to the manuscript. Go to Neurology.org/N for full disclosures.

\section{References}

1. Otto C, Coppit G, Mazzoli R, et al. Gaze-evoked amaurosis, a report of five cases. Ophthalmology 2003;110:322-326.

2. Shapey J, Sabin H, Danesh-Meyer H, Kaye A. Diagnosis and management of optic nerve sheath meningiomas. J Clin Neurosci 2013;20:1045-1056. 


\section{Neurology}

\section{Teaching NeuroImages: Optic nerve sheath meningioma presenting as gaze-evoked amaurosis}

Stephen A. Abraham Johnson, John J. Chen and W. Oliver Tobin

Neurology 2018;90;e2095-e2096

DOI 10.1212/WNL.0000000000005642

This information is current as of June 4, 2018

\section{Updated Information \& Services}

References

Subspecialty Collections

Permissions \& Licensing

Reprints including high resolution figures, can be found at: http://n.neurology.org/content/90/23/e2095.full

This article cites 2 articles, 0 of which you can access for free at: http://n.neurology.org/content/90/23/e2095.full\#ref-list-1

This article, along with others on similar topics, appears in the following collection(s):

Nerve tumor

http://n.neurology.org/cgi/collection/nerve_tumor Optic nerve

http://n.neurology.org/cgi/collection/optic_nerve

Visual loss

http://n.neurology.org/cgi/collection/visual_loss

Information about reproducing this article in parts (figures,tables) or in its entirety can be found online at:

http://www.neurology.org/about/about_the_journal\#permissions

Information about ordering reprints can be found online:

http://n.neurology.org/subscribers/advertise

Neurology ${ }^{\circledR}$ is the official journal of the American Academy of Neurology. Published continuously since 1951, it is now a weekly with 48 issues per year. Copyright (O) 2018 American Academy of Neurology. All rights reserved. Print ISSN: 0028-3878. Online ISSN: 1526-632X.

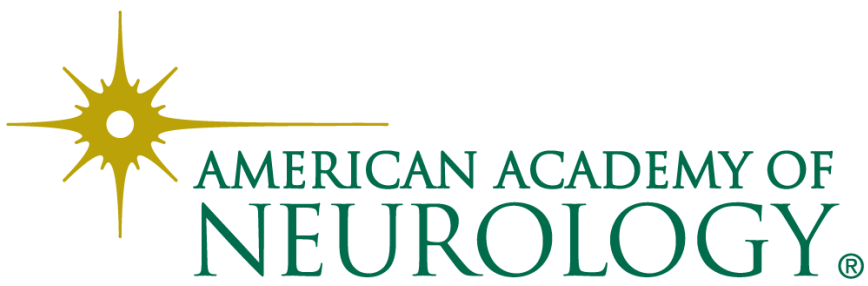




\section{Neurology}

\section{Teaching NeuroImages: Optic nerve sheath meningioma presenting as gaze-evoked amaurosis}

Stephen A. Johnson, John J. Chen and W. Oliver Tobin

Neurology 2018;90;e2095-e2096

DOI 10.1212/WNL.0000000000005642

\section{This information is current as of June 4, 2018}

\section{Updated Information \& Services}

References

Subspecialty Collections

Errata

Permissions \& Licensing

\section{Reprints}

including high resolution figures, can be found at: http://n.neurology.org/content/90/23/e2095.full

This article cites 2 articles, 0 of which you can access for free at: http://n.neurology.org/content/90/23/e2095.full\#ref-list-1

This article, along with others on similar topics, appears in the following collection(s):

Nerve tumor

http://n.neurology.org/cgi/collection/nerve_tumor

Optic nerve

http://n.neurology.org/cgi/collection/optic_nerve

Visual loss

http://n.neurology.org/cgi/collection/visual_loss

An erratum has been published regarding this article. Please see next page or:

/content/early/2023/01/30/WNL.0000000000201643.full.pdf

Information about reproducing this article in parts (figures,tables) or in its entirety can be found online at:

http://www.neurology.org/about/about_the_journal\#permissions

Information about ordering reprints can be found online:

http://n.neurology.org/subscribers/advertise

Neurology ${ }^{\circledR}$ is the official journal of the American Academy of Neurology. Published continuously since 1951 , it is now a weekly with 48 issues per year. Copyright @ 2018 American Academy of Neurology. All rights reserved. Print ISSN: 0028-3878. Online ISSN: 1526-632X.






\section{Neurology Publish Ahead of Print \\ DOI: 10.1212/WNL.0000000000201643}

\section{CORRECTION \& REPLACEMENT}

\section{Teaching Neurolmages: Optic Nerve Sheath Meningioma Presenting as Gaze-Evoked Amaurosis}

In the Resident and Fellow Section article "Teaching Neurolmages: Optic Nerve Sheath Meningioma Presenting as Gaze-Evoked Amaurosis" by Johnson et al. ${ }^{1}$, the first author's name should be listed as "Stephen A. Johnson." The article has been replaced by a corrected version. The publisher regrets the error.

\section{REFERENCE}

1 Johnson SA, Chen JJ, Tobin WO. Teaching neuroimages: optic nerve sheath meningioma presenting as gaze-evoked amaurosis. Neurology. 2018;90(23):e2095-e2096.

Neurology® Published Ahead of Print articles have been peer reviewed and accepted for publication. This manuscript will be published in its final form after copyediting, page composition, and review of proofs. Errors that could affect the content may be corrected during these processes. 